\title{
Effect of the p38 kinase inhibitor, SB 203580, on sephadex induced airway inflammation in the rat
}

\author{
M. Birrell, D. Hele, K. McCluskie, S. Webber, M. Foster, M.G. Belvisi
}

Effect of the p38 kinase inhibitor, SB 203580, on sephadex induced airway inflammation in the rat. M. Birrell, D. Hele, K. McCluskie, S. Webber, M. Foster, M.G. Belvisi. CERS Journals Ltd 2000

ABSTRACT: SB 203580 is a pyridinyl imidazole compound which inhibits the release of pro-inflammatory cytokines, such as tumour necrosis factor- $\alpha$ (TNF- $\alpha)$ and interleukin-1 $\beta$ (IL-1 $\beta$ ), in vitro and in vivo by inhibiting p38 mitogen-activated protein kinase (MAPK).

The present study investigated the effects of SB 203580 in a model of airway inflammation induced by the topical administration of Sephadex into the rat airways. This inflammatory response is characterized by the development of lung oedema, airway tissue inflammatory cell recruitment and an increase in lung TNF- $\alpha$ and IL-1 $\beta$ levels.

Sephadex-induced lung oedema was accompanied by a significant increase in lung tissue TNF- $\alpha$ but not IL-1 $\beta$ levels. There was also a significant increase in lung tissue macrophages and an increase in eosinophils which did not reach significance. SB 203580 administration significantly inhibited lung oedema $\left(E D 50=18 \mathrm{mg} \cdot \mathrm{kg}^{-1}\right)$ in a dose-related manner but was without significant effect on lung tissue cell recruitment or cytokine levels.

These data suggest that the increase in tumour necrosis factor- $\alpha$ and lung oedema are separate processes which both contribute to Sephadex pathology. Furthermore, the inhibitory effect of SB 203580 on Sephadex-induced lung oedema suggests that p38 kinase inhibitors may be of use in pulmonary pathologies in which lung oedema is a feature.

Eur Respir J 2000; 16: 947-950.

The Sephadex model of lung oedema in the rat is a model characterized by acute alveolitis and bronchiolitis, leading to inflammatory cell infiltration and interstitial oedema. In fact this model appears to parallel many of the pathophysiological features associated with human interstitial lung diseases [1]. This model has been used previously to demonstrate the anti-inflammatory properties of compounds such as glucocorticosteroids and ebselen based upon their ability to modulate lung oedema [2, 3].

SB 203580 (4-(4-fluorophenyl)-2-(4-methylsulphinylphenyl)-5-(4-pyridyl) imidazole) is a pyridinyl imidazole compound which inhibits interleukin (IL)-1 $\beta$ and tumour necrosis factor (TNF- $\alpha$ ) production from human monocytes [4]. The molecular target of this and related compounds has been identified as p38 mitogen-activated protein kinase (MAPK) [4]. In addition to in vitro data, p38 kinase inhibitors, such as SB 203580, have been shown to inhibit LPS-induced systemic TNF- $\alpha$ release in rats $[5,6]$ and has been shown to be efficacious in in vivo models of arthritis [5] and inflammatory angiogenesis [7]. Furthermore, it has recently been demonstrated that in the airways SB 203580 inhibits bronchoalveolar (BAL) IL-1 $\beta$ levels and the associated neutrophilia in an LPS-induced model of airway inflammation in the rat [6] and BAL TNF- $\alpha$ levels following allergen challenge in sensitized Brown Norway rats [8].
Pharmacology Dept, Research \& Development, Aventis Pharma, Dagenham Research Centre, Dagenham, Essex, UK.

Correspondence: M.G. Belvisi

Respiratory Pharmacology

Cardiothoracic Surgery

Imperial College of Science, Technology and Medicine

National Heart and Lung Institute

Dovehouse street

London

SW3 6LY

Fax: 4402073518126

Keywords: Airway inflammation lung oedema

sephadex

tumour necrosis factor- $\alpha$

Received: March 62000

Accepted after revision July 142000
Increased levels of TNF- $\alpha$ in the airways following Sephadex treatment have been suggested to play a causative role in Sephadex-induced lung pathology [9]. In this study the effect of SB 203580 on Sephadex-induced airway inflammation in the rat was examined.

\section{Materials and methods}

\section{Animals}

Male, Sprague-Dawley rats (330-350 g) were purchased from Harlan-Olac (Bicester, UK) and housed for 1 week before initiating experiments. Food and water were supplied ad libitum. UK Home Office guidelines for animal welfare based on the Animals (Scientific Procedures) Act 1986 were strictly observed.

\section{Methods}

Rats were dosed intratracheally (i.t.) with vehicle (saline) or Sephadex beads $\left(5 \mathrm{mg} \cdot \mathrm{kg}^{-1}\right)$ at a dose volume of 1 $\mathrm{mL} \cdot \mathrm{kg}^{-1}$ under halothane anaesthesia $(4 \%$ in oxygen for 3 $\min )$. SB $203580\left(1,3,10,30 \& 100 \mathrm{mg} \cdot \mathrm{kg}^{-1}\right)$ or vehicle $(1 \%$ carboxymethyl cellulose $(\mathrm{CMC})$ in distilled water, 2 
$\mathrm{mL} \cdot \mathrm{kg}^{-1}$ ) were administered orally $1 \mathrm{~h}$ prior to and $5 \mathrm{~h}$ post Sephadex administration. The positive standard, dexamethasone $\left(1 \mathrm{mg} \cdot \mathrm{kg}^{-1}\right)$ was dosed orally 24 and $1 \mathrm{~h}$ prior to Sephadex.

\section{Measurement of lung oedema}

Rats were killed $24 \mathrm{~h}$ post-Sephadex by sodium pentobarbitone $\left(200 \mathrm{mg} \cdot \mathrm{kg}^{-1}\right.$, i.p.) overdose, the heart and lungs were removed en bloc, and the lung wet weights determined and expressed per $100 \mathrm{~g}$ initial body weight. Percentage inhibition of oedema compared to the Sephadex i.t./vehicle p.o. control group was then determined for each treatment group. A dose-response curve was generated, a sigmoidal fit obtained for the data and an ED50 value (dose that produced $50 \%$ of the maximum inhibition of lung oedema) calculated.

\section{Measurement of cytokine protein levels in the lung tissue}

After weighing the rat lung, approximately $500 \mathrm{mg}$ of the lung tissue was chopped and flash frozen in liquid nitrogen and stored at $-20^{\circ} \mathrm{C}$ until needed. Approximately $250 \mathrm{mg}$ of lung tissue was weighed and homogenized with $1 \mathrm{~mL}$ of ice cold saline. The homogenized sample was then spun at $800 \mathrm{~g}$ for $10 \mathrm{~min}$. The resulting supernatant was taken off and stored at $-20^{\circ} \mathrm{C}$. TNF- $\alpha$ and IL- $1 \beta$ levels in the lung tissue supernatant were determined using a rat specific enzyme-linked immunosorbent assay (ELISA).

\section{Measurement of cell recruitment in the lung tissue}

After weighing the rat lungs for oedema determination, one lobe of the lung was removed and perfused with ice cold Roswell Park Memorial Institute medium (RPMI) to remove any blood and then finely chopped. The amount and type of white blood cells in the lung tissue were determined by incubating the chopped lung tissue with $10 \mathrm{~mL}$ of RPMI containing collagenase $\left(1 \mathrm{mg} \cdot \mathrm{mL}^{-1}\right)$ and DNase $\left(25 \mu \mathrm{g} \cdot \mathrm{mL}^{-1}\right)$ in a shaking water bath at $37^{\circ} \mathrm{C}$ for $1 \mathrm{~h}$. The recovered cells were then passed through a $70 \mu \mathrm{m}$ cell sieve and spun at $800 \mathrm{~g}$ for $10 \mathrm{~min}$ at $4^{\circ} \mathrm{C}$. The supernatant was discarded, $10 \mathrm{~mL}$ of RPMI added and the pellet resuspended. The pellet washing step was carried out twice to remove the collagenase and DNase. After the final wash the pellet was resuspended in $1 \mathrm{~mL}$ of RPMI. Total white blood cell counts were determined on an automated cell counter (Cobas Argos, Roche ABX Hematologie, Montpellier, France). Cytospins of these samples were prepared by centrifugation of $100 \mu \mathrm{L}$ aliquots in a cytospin (Shandon, Runcorn, UK) at $800 \mathrm{~g}$ for $5 \mathrm{~min}$ at room temperature. Slides were fixed and stained on a Hema-tek 2000 (Ames Co., Elkhart, USA) with modified Wrights-Giemsa stain. Four part differential counts on 200 cells per slide were performed following standard morphological criteria and the percentage of eosinophils, macrophages/monocytes, lymphocytes and neutrophils were determined [10].

\section{Materials}

SB 230580 (4-(4-fluorophenyl)-2-(4-methylsulphinylphenyl)-5-(4-pyridyl) imidazole) was synthesized by the Medicinal Chemistry Department at Aventis Pharma (Dagenham, Essex, UK). Euthatal and halothane were obtained from Rhône Mérieux (Harlow, UK) and RPMI from GIBCO (Paisley, UK). Roche Diagnostics (Lewes, UK) supplied the DNase and collagenase. Sephadex G-200 was purchased from Pharmacia (Uppsala, Sweden). CMC and dexamethasone were purchased from Sigma (Poole, UK). TNF- $\alpha$ ELISA kits were from R\&D systems (Abingdon, UK) and IL-1 $\beta$ ELISA kits were from Lifescreen (Watford, UK).

\section{Analysis}

All values are presented as mean \pm SEM from $n=8$ rats per group. The percentage inhibition of oedema (compared to the Sephadex administered, vehicle-treated group) was determined for each treated group. The dose-response curve for inhibition of lung oedema by SB 203580 was calculated by least squares, non-linear iterative regression with the "PRISM" curve fitting programme (Graphpad Instat software programme, San Diego, CA, USA). An ED50 value (dose of SB 203580 required to produce 50\% of the maximum inhibition) was subsequently interpolated from a curve of best fit. The data were analysed using the Kruskal-Wallis nonparametric test with a correction for multiple comparison's using Dunnett's critical values. A pvalue of less than 0.05 was considered to be statistically significant $(*: \mathrm{p}<0.05$ and $* *: \mathrm{p}<0.01)$.

\section{Results}

\section{Lung oedema}

Sephadex instillation evoked a significant oedema $(21 \%$, $\mathrm{p}<0.01)$. SB 203580 produced a dose-dependent inhibition of lung oedema (ED50 of $18 \mathrm{mg} \cdot \mathrm{kg}^{-1}$ ) when compared to Sephadex-instilled, vehicle-treated animals (fig. 1). Dexamethasone $\left(1 \mathrm{mg} \cdot \mathrm{kg}^{-1}\right)$ significantly reduced lung wet weight $(117 \%$ inhibition, $\mathrm{p}<0.01)$.

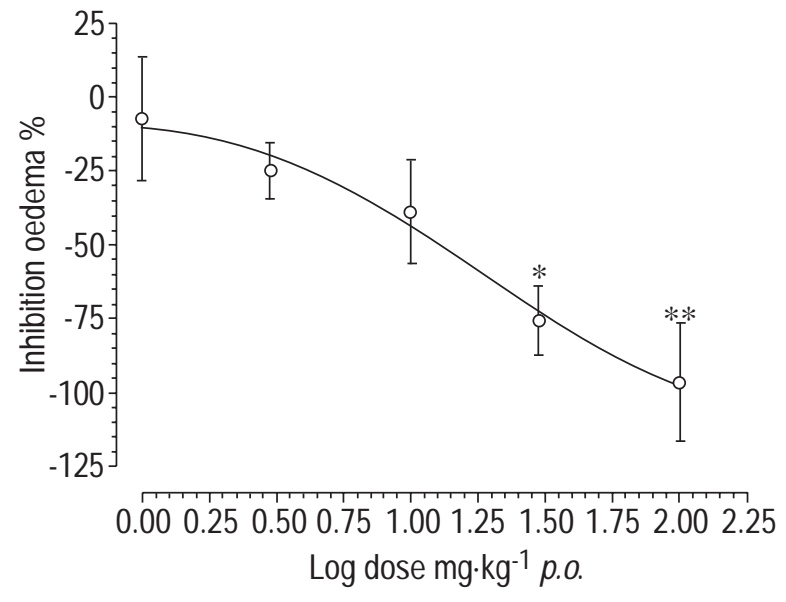

Fig. 1. - Effect of the p38 inhibitor, SB 203580, on Sephadex-induced lung oedema. Percentage inhibition of Sephadex-induced lung oedema by SB $203580\left(1-100 \mathrm{mg} \cdot \mathrm{kg}^{-1}\right.$, administered $1 \mathrm{~h}$ before and $5 \mathrm{~h}$ after Sephadex instillation, p.o.). Points represent meansem of 8 rats. ED50=18 $\mathrm{mg} \cdot \mathrm{kg}^{-1}$. *: p<0.05; **: $\mathrm{p}<0.01$. 
Cytokine protein levels in the lung tissue

Sephadex treatment significantly increased lung tissue TNF- $\alpha$ levels $150.6 \pm 27.2$ to $1104.7 \pm 243.9$ pg.g lung tissue $^{-1}(733 \%, \mathrm{p}<0.01)$ but had no impact, in this study, on IL-1 $\beta$ levels in the lung tissue. SB 203580, at the doses tested, did not significantly impact on either cytokine, whereas dexamethasone significantly reduced both TNF- $\alpha$ (from $1104.7 \pm 243.9$ to $207.95 \pm 20.91 \mathrm{pg} \cdot \mathrm{g}$ lung tissue $\left.^{-1}, \mathrm{p}<0.01\right)$ and IL-1 $\beta(6175.5 \pm 371.6$ to $3547.3 \pm$ $334.2 \mathrm{pg} \cdot \mathrm{g}^{-1}$ lung tissue, $\mathrm{p}<0.01$ ) (figs. $2 \mathrm{a}$ and $\mathrm{b}$ ).

\section{Inflammatory cell content in the lung tissue}

Sephadex instillation caused an increase in lung tissue macrophages $\left(5.2 \pm 0.6\right.$ to $10.5 \pm 1.9$ cell $10^{3} \mathrm{~g} \cdot$ tissue $^{-1}$, $\mathrm{p}<0.05)$ and eosinophils $\left(0.79 \pm 0.26\right.$ to $2.39 \pm 0.78$ cell $\times 10^{3}$ g.tissue $\left.{ }^{-1}, \mathrm{p}=0.05\right)$, however, neutrophils were unaffected. SB 203580 treatment did not significantly affect inflammatory cell number, whereas dexamethasone significantly reduced eosinophil number $(2.39 \pm 0.78$ to $0.22 \pm 0.035$ cell $\times 10^{3} \mathrm{~g} \cdot$ tissue $\left.^{-1}, \mathrm{p}=0.01\right)$, neutrophil number $(7.71 \pm 1.95$ to $2.75 \pm 0.30$ cell $\times 10^{3} \mathrm{~g} \cdot$ tissue $\left.^{-1}, \mathrm{p}=0.01\right)$ and macrophage number $\left(10.5 \pm 1.9\right.$ to $1.8 \pm 0.2$ cell $\times 10^{3} \mathrm{~g} \cdot$ tissue $\left.^{-1}, \mathrm{p}=0.01\right)$.
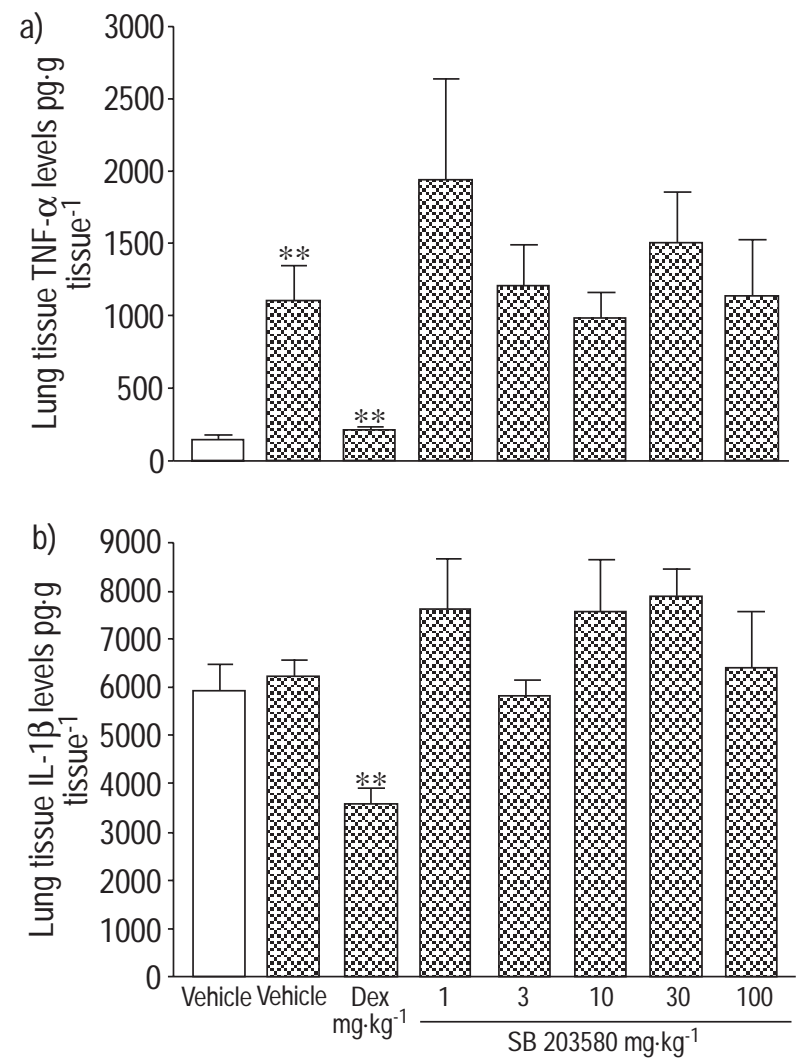

Fig. 2. - Effect of the p38 inhibitor, SB 203580, on Sephadex-induced cytokine production in lung tissue. Effect of SB $203580\left(1-100 \mathrm{mg} \cdot \mathrm{kg}^{-1}\right.$, p.o.) on Sephadex-induced tumour necrosis factors- $\alpha$ (a) and interleukin-1 $\beta$ (b) levels and in lung tissue as measured by rat specific enzyme-linked immunosorbent assay. Data are expressed as the mean \pm SEM of 8 rats. Dex: dexamethasone; THF- $\alpha$ : tumour necrosis factor- $\alpha$; IL-1 $\beta$ : interleukin-1 $\beta$. $\square$ : vehicle alone; : Sephadex challenge. Statistical significance was assessed by Kruskal Wallis with a correction for Dunnett's critical values. $\left(*\right.$ : $\mathrm{p}<0.05,{ }^{* *}$ : $\left.\mathrm{p}<0.01\right)$.

\section{Discussion}

Recently, attention has focused on the MAPK superfamily due to their consistent activation by pro-inflammatory cytokines and to their role in nuclear signalling. Interest in one of these families, the p38 family, has been particularly intense following the discovery that p38 inhibitors are anti-inflammatory in in vivo models of arthritis and inflammatory angiogenesis $[4,5,7]$. However, the role and the contribution of p38 kinase in airway inflammation is less clear. In this study the effect of SB 203580 on Sephadex-induced airway inflammation has been investigated.

SB 203580 significantly inhibited Sephadex induced lung oedema in a dose-dependent manner achieving an ED50 of $18 \mathrm{mg} \cdot \mathrm{kg}^{-1}$. The potency of SB 203580 in this model agrees with data obtained in models of arthritis in mice and rats where the effect is attributed to inhibition of p38 kinase [5]. Although a nonspecific action of the compound, unrelated to its inhibitory action on p38 kinase, cannot be ruled out. Alternatively, SB 203580 failed to impact on inflammatory cell recruitment into lung tissue or on TNF- $\alpha$ and IL-1 $\beta$ levels in lung tissue. However, the steroid, dexamethasone, which was used as a positive control completely abrogated Sephadexinduced lung oedema, cell recruitment into the lung tissue and TNF- $\alpha$ levels in the lung tissue. The inability of SB 203580 to inhibit the Sephadex-induced increase in TNF- $\alpha$ levels in the lung tissue cannot be attributed to the bioavailability and tissue distribution of the compound since the compound did have an inhibitory action on lung oedema. Previously the authors have shown that SB 203580 inhibits LPS-induced systemic TNF- $\alpha$ release but not aerosolized LPS-induced airway TNF- $\alpha$ release into BAL fluid and the associated initial phase of neutrophilia obtained in this model [6]. Therefore, the inability of SB 203580 to impact on airway tissue TNF- $\alpha$ levels after Sephadex is not such a surprising finding. However, this phenomenon appears to be stimulus specific since SB 203580 has been shown to inhibit the increase in BAL TNF- $\alpha$ levels following allergen challenge in sensitized Brown Norway rats [8].

The reasons for the lack of effect of SB 203580 on TNF$\alpha$ levels are not clear but could be related to the differential expression and sensitivity of the different $\mathrm{p} 38$ isoforms to inhibition by SB 203580. SB 203580 has been shown to inhibit $\mathrm{p} 38-\alpha$ and $\mathrm{p} 38-\beta$ but not $\mathrm{p} 38-\gamma$ and $\mathrm{p} 38-\delta$ [11]. Thus, if $\mathrm{p} 38-\gamma$ and $\mathrm{p} 38-\delta$ are the predominant isoforms involved in the release of TNF- $\alpha$ in the lung tissue following Sephadex this could explain the apparent ineffectiveness of SB 203580. Alternatively, it may be that the release of TNF- $\alpha$ may not be solely controlled via the p38 kinase signal transduction pathway and could be due to activation of other signalling pathways. In fact, both p38 and ERK are involved in LPS-induced TNF- $\alpha$ production from macrophages in vitro [12].

Sephadex-induced inflammatory cell recruitment into the rat lung was not inhibited by SB 203580. In contrast to these observations, the authors have recently reported that SB 203580 inhibited an LPS-induced increase in neutrophils and IL-1 $\beta$ in the lung tissue [6]. However, the inflammatory cell and cytokine release profile in the Sephadex model is completely different to that induced by aerosolized LPS. In this study, however, the stimulus 
used to produce the inflammatory response was Sephadex rather than LPS, and Sephadex did not evoke an increase in neutrophils and IL-1 $\beta$, therefore, the effect of SB 203580 on this axis could not be tested. In fact, this observation is consistent with a previous study by the authors where TNF- $\alpha$, endothelin- 1 but not IL- $1 \beta$ levels were elevated in BAL fluid from rats $24 \mathrm{~h}$ following i.t. Sephadex treatment [3].

To conclude, these data suggest that the increase in lung tissue tumour necrosis factor- $\alpha$ and lung oedema are separate processes which may both contribute to Sephadex pathology and that the development of lung oedema after Sephadex is not dependent on the release of this cytokine. However, it is possible that inhibitors of p38 kinase may be responsible for the reduction of Sephadex-induced lung oedema and that inhibitors of this class may be of use in pulmonary pathologies in which lung oedema is a feature.

\section{References}

1. Cotgreave IA, Johansson U, Westergren PW, Moldeus $\mathrm{PW}$, Brattsand R. The anti-inflammatory activity of ebselen but not thiols in experimental alveolitis and bronchiolitis. Agents and Actions 1988; 24: 313-319.

2. Källstrom L, Brattsand R, Lövgren U, Svensjö E, Roempke K. A rat model for testing anti-inflammatory action in lung and the effect of glucocorticoids (CGS) in this model. Agents and Actions 1985; 17: 355-357.

3. Belvisi MG, Haddad E-B, Battram C, Birrell MA, Foster M, Webber SE. Anti-inflammatory properties of Ebselen in a model of Sephadex-induced lung inflammation. Eur Respir J 2000; 15: 579-581.

4. Lee JC, Laydon JT, McDonnell PC, et al. A protein kinase involved in the regulation of inflammatory cytokine biosynthesis. Nature 1994; 372: 739-746.

5. Badger AM, Bradbeer JN, Votta B, Lee JC, Adams JL,
Griswold DE. Pharmacological profile of SB 203580, a selective inhibitor of cytokine suppressive binding protein/p38 kinase, in animal models of arthritis, bone resorption, endotoxin shock and immune function. $J$ Pharmacol Exp Ther 1996; 279: 1453-1461.

6. Haddad E-B, Birrell MA, McCluskie K, et al. Effect of the p38 kinase inhibitor, SB 203580, on IL-1b levels and cell influx in a model of airway inflammation. Am $J$ Respir Crit Care Med 1999; 159: A331.

7. Jackson JR, Bolognese B, Hillegass L, et al. Pharmacological effects of SB 220025, a selective inhibitor of p38 mitogen-activated protein kinase, in angiogenesis and chronic inflammatory disease models. $J$ Pharmacol Exp Ther 1998; 284: 687-692.

8. Escott KJ, Belvisi MG, Birrell MA, Webber SE, Foster ML, Sargent C. Effect of the p38 kinase inhibitor, SB203580, on allergic airway inflammation in the rat. $\mathrm{Br}$ $J$ Pharmacol 2000; 131: 173-176.

9. Gater PR, Renzetti LM. Ro 45-2081, a TNF receptor fusion protein, prevents inflammatory responses in the airways. Agents Actions Suppl 1998; 49: 67-71.

10. Underwood SL, Raeburn D, Lawrence C, Foster M, Webber S, Karlson J-A. RPR 106541, a novel, airwaysselective glucocorticoid: effects against antigen-induced CD4+ $\mathrm{T}$ lymphocyte accumulation and cytokine gene expression in the Brown Norway rat lung. $\mathrm{Br} J$ Pharmacol 1997; 122: 439-446.

11. Kumar S, McDonnell PC, Gum RJ, Hand AT, Lee JC, Young PR. Novel homologues of CSBP/p38 MAP kinase: activation, substrate specificity and sensitivity to inhibition by pyridinyl imidazoles. Biochem Biophys Res Commun 1997; 235: 533-538.

12. Ajizian SJ, English BK, Meals EA. Specific inhibitors of p38 and extracellular signal-regulated kinase and mitogenactivated protein kinase pathways block inducible nitric oxide synthase and tumor necrosis factor accumulation in murine macrophages stimulated with lipopolysaccharide and interferon-gamma. J Infect Dis 1999; 179: 939-944. 